\title{
Legal Politic of Fishermen Empowerment in Indonesia
}

\author{
Lucky Dafira Nugroho* \\ Faculty of Law \\ Trunojoyo University Of Madura \\ Bangkalan, Indonesia \\ lucky.dafira@trunojoyo.ac.id
}

\author{
Aprilina Pawestri \\ Faculty of Law \\ Trunojoyo University Of Madura \\ Bangkalan, Indonesia \\ aprilina.pawestri@trunojoyo.ac.id
}

\begin{abstract}
Fishermen poverty is still national problem that needs to be solved. Based on the latest data, from 25.95 million poor people in Indonesia, almost $45 \%$ work as fishermen. It shows that fishermen need help from the state to improve their welfare, considering that this is also the state responsibility as stipulated in Article $28 \mathrm{H}$ paragraph (1) - (3) of the 1945 Constitution of the Republic of Indonesia. In this condition, the state seeks to improve the welfare of fishermen through several policies by first making regulations in a law. Regulations in the maritime sector include 4 (four) laws, namely (1) Law 7/2016 concerning Protection and Empowerment of Fishermen, Fish Cultivators, and Salt Farmers, (2) Law 31/2004 concerning Fisheries and their amendments, (3) Law 32 / 2014 concerning Maritime Affairs and Law 27/2007 concerning Management of Coastal Areas and Small Islands and their amendments. Specifically, fisheries empowerment regulations in Indonesia are regulated in the Law on Protection and Empowerment of Fishermen, Fish Cultivators, and Salt Farmers which have been realized in government programs, in the form of coastal economic empowerment programs (PEMP), fishermen insurance premium subsidy programs in the first year, and help of fishing gear / boat for small and traditional fishermen. For the regulation of the Maritime Law, the Fisheries Law and the Management of Coastal and Small Islands Regulations concerning marine governance so that it can be used effectively and efficiently. The political policy of empowering fishermen in Indonesia is regulated in the Law on Protection and Empowerment of Fishermen, Fish Cultivators, and Salt Farmers as form of economic sector development. While the legal politic of other marine sector development includes development in ecological and social aspects. Ecological aspects are regulated through the Management of Coastal Areas and Small Islands and their amendments governing restrictions on the use of coastal areas. The social aspects of marine related to the handling of fishermen conflicts due to territorial boundaries and means of business of fishermen which are caused by economic gaps between fishermen are overcome by the regulation of the Maritime Law and the Fisheries Law whose substance regulates IUU (Illegal, Unreported, and Unregulated) and its law enforcement.
\end{abstract}

Keywords: Politic, Law, Fishermen, Indonesia

\section{INTRODUCTION}

The presence of Indonesia, which is the largest archipelagic country in the world with an ocean area of 3.25 million $\mathrm{km}^{2}$ and 2.55 million $\mathrm{km}^{2}$ Exclusive Economic Zone (EEZ) correlates with the average profession of the coastal population as fishermen. Fishermen are also divided into 2 (two) groups, namely marine fishermen and inland water fishermen. The sea fishermen are divided into several categories, namely small fishermen, traditional fishermen, labor fishermen and owner fishermen. The national number of fishermen in Indonesia in 2017 of 2.7 million majority are in the poverty line, it accounts for $25 \%$ of the national poverty rate. [1] But in reality there are still many fishermen in Indonesia, especially small fishermen, traditional fishermen and labor fishermen who are not yet prosperous or poor.

The condition can be compared to the total number of poor people in Indonesia in March 2018 based on data from the Central Statistics Agency (BPS) of the Republic of Indonesia. The number of poor people (residents with per capita expenditure per month below the Poverty Line) in Indonesia reaches 25.95 million people or around 9.82 percent. [2] From the 25.95 million poor population, 48\% are residents who work as marine fishermen and $30 \%$ are inland water fishermen. Poverty problem experienced by the Indonesian population as a whole especially for fishermen who inhabit the coast still need serious handling. According to Mubyarto, Indonesian fishing communities are the poorest of the poorest groups (the poorest of the poor). [3] There are signs of poverty, namely (1) those who live below the poverty line do not have factors of production, such as sufficient land, capital or skills, (2) They generally do not have the possibility to acquire production assets with their own strength, (3) The level of education is generally low, not graduating from elementary school, (4) the living habits of fishermen who do not take into account their future needs, (5) small modes of ownership, (6) the lack of the role of economic institutions that deliver results. In addition, technological factors also have an important role. [4]

Many factors that cause fishermen in Indonesia are still below the poverty line, which should not happen considering the Indonesian marine products (fish catches in particular) are very capable of providing economic value for fishermen. This condition is getting worse, entering early 2020 when Indonesia experienced covid-19. The impact of covid-19 was also felt by fishermen, many of them did not sail, so there is nothing could be sold (no income). This is not only the responsibility of the fishermen themselves, but also the need for the involvement of local and central government to be able to break the chain of poverty of fishermen, especially in this covid-19 time. Although it 
cannot be denied that the government already has regulations related to the regulation of fishermen, specifically through the Ministry of Maritime Affairs and Fisheries (KKP) of the Republic of Indonesia. However, when referring to the data, the poverty rate of fishermen is still quite high to date. Even the fishing profession began to decrease due to the rampant illegal fishing. [5]

The central government and local governments, both provincial and regency / city governments, with various breakthrough of fisherman empowerment programs have not yet fully overcome the poverty of small and traditional fishermen in Indonesia. One of the programs created by the Government is a fisherman insurance premium assistance program that is provided in the first year. The fisherman insurance premium in the second year is expected to be paid independently by the fisherman. However, the fact is that fishermen are reluctant to pay the fishermen's insurance premium independently so that the program only lasts in the first year when there is subsidy from the central government.

The fishermen empowerment programs must first be stated in regulation as form of public policy realization from the Government. The policy must then be implemented so that the goal of fishermen poverty alleviation who become the main target can be achieved. According to Budi Mulianto, social welfare is "a great achievement in the conditions of human life as a whole in each of his joints, including the conditions of social, spiritual and material". [6] Optimization of fishermen empowerment as form of poverty alleviation by involving fishermen in government programs are a solution, As stated by Aprilina Pawestri et al, "the fishermen empowerment program carried out by the government is a state obligation to fulfill the fishermen's rights so that the fishermen prosper". [7] Further explained by Aprilina Pawestri et al. That "the fulfillment of citizens' rights, especially fishermen, to realize welfare as stipulated in Article $28 \mathrm{H}$ paragraph (1) - (3) of the 1945 Constitution of the Republic of Indonesia and Law No. 7 of 2016 has confirmed state responsibilities under Article 71 of Law No. 39 of 1999 ". [8]

Based on the background outlined above, the legal issue of this article is the direction of public policy on the fishermen empowerment in Indonesia as effort to alleviate fishermen's poverty. From these legal issues, 2 (two) problem statements can be drawn, namely:

1. How are the regulations of fishermen empowerment in Indonesia?

2. How is the legal politic of fishermen empowerment so that fishermen can prosper?

\section{RESEARCH METHOD}

To answer the problem in this article, a normative juridical research method will be used that will examine the direction of the policy of marine fishermen empowerment in Indonesia through legislative approach to find out regulations related to fishermen and will specifically focus on the political policy of fishermen empowerment, specifically will focus on the public policy on fishermen empowerment that have been made by the Indonesian government.

\section{RESULT AND DISCUSSION}

\section{1) Regulation of fishermen empowerment in Indonesia}

Regulations related to the maritime sector in Indonesia consist of:

(1) Law No. 7 of 2016 concerning Protection and Empowerment of Fishermen, Fish Cultivators, and Salt Farmers;

(2) Law Number 31 of 2004 concerning Fisheries and their amendments;

(3) Law Number 32 Year 2014 Regarding Maritime Affairs;

(4) Law Number 27 of 2007 concerning Management of Coastal Areas and Small Islands and their amendments.

The Law on the Protection and Empowerment of Fishermen, Fish Cultivators, and Salt Farmers in outline regulates the protection and empowerment of fishermen, starting with the planning, implementation, funding and financing stages, and supervision accompanied by criminal sanctions for violations. Protection here aims to help fishermen who face difficulties related to fishing businesses. While the empowerment of fishermen has the aim to improve the ability of fishermen in carrying out fishing businesses. Not only that, the community is also given space to participate in planning, implementation, funding and financing, and supervision. This is a form of community participation.

The Fisheries Law and its amendments are regulations that in outline govern marine resource management so that fish management is effective and efficient and provides more opportunities for traditional fishermen and small fishermen. The Fisheries Law is also in response to the issue of fisheries development that tends to harm traditional and small fishermen, namely the symptoms of over fishing, fish theft, and other illegal fishing actions. [9] Therefore, the existence of this Law on Fisheries regulates the supervision and law enforcement of the existence of illegal fishing, fisheries management which includes fisheries port, conservation, licensing, and harness. In addition, also arrangements regarding the authority of the fisheries court.

The Maritime Law is a regulation that regulates marine management, management of marine space, protection of the marine environment, and law enforcement at sea. Maritime Law is substitute for Law No. 6 of 1996 concerning Water and has been elaborated in several implementing regulations which include Governmental Regulation No. 32 of 2019 concerning Sea Spatial Planning, Presidential Regulation 178 
of 2014 concerning Maritime Security Agency, Presidential Regulation 16 of 2017 concerning Indonesian Maritime Policy, Presidential Regulation 83 of 2018 concerning Handling of Marine Waste, and Presidential Regulation 56 of 2019 of the National Action Plan for Integrated Management of National Parks and National Water Conservation Areas 2018-2012.

The Law on the Management of Coastal Areas and Small Islands and their Amendments regulates the planning, supervision, utilization, supervision and control of coastal and small island resources between the central government, regional governments, villages, communities, and the private sector. The Law on the Management of Coastal Areas and Small Islands has been followed up with (1) Governmental Regulation Number 62 of 2010 concerning Utilization of Outermost Small Islands, (2) Governmental Regulation Number 64 of 2010 concerning Disaster Mitigation in Coastal Areas and Small Islands, (3) Presidential Regulation Number 73 of 2015 concerning Implementation of National Coastal Region and Small Islands Management Coordination, (4) Presidential Regulation Number 51 of 2016 concerning Coastal Boundaries, (5) Presidential Regulation Number 32 of 2018 concerning Management Authority Institution of Labuan Bajo Flores Tourism Area, (6) Presidential Regulation No. 83 of 2018 concerning Sea Waste Management, (7) Presidential Regulation No. 56 of 2019 concerning National Action Plan for Integrated Management of National Parks and National Water Conservation Areas 2018-2025, and (8) Presidential Decree No. 6 of 2017 concerning Determination of the Outermost Small Islands.

From the four laws that govern fishermen empowerment, the Law on the Protection and Empowerment of Fishermen, Fish Cultivators, and Salt Farmers. The law is the legal basis for making public policies in the form of subsidies and assistance to small and traditional fishermen. While the regulation of the Fisheries Law and its amendments, the Maritime Law, and the Management of Coastal and Small Islands Areas and their amendments regulate governance in the marine environment and the most important is the regulation regarding the enforcement of illegal fishing law which often detrimental to small and traditional fishermen. The loss experienced by traditional fishermen and small fishermen due to illegal fishing activities is the destruction of the ecosystem and also the competition between traditional and small fishermen due to the lack of sophisticated fishing equipment owned, which results in reduced catches. Which affects the income of fishermen.

Government programs that have been carried out as form of follow-up to policies that have been made by the central government based on the Law on the Protection and Empowerment of Fishermen, Fish Cultivators, and Salt Farmers are as follows:

(1) Coastal community economic empowerment program (PEMP), which is developed nationally. This program is specifically aimed at improving the welfare of coastal communities through economic and social institutional approaches. [10]
(2) Subsidies for fisherman insurance premiums. Although this subsidy is given only in the first year. Whereas in the second year fishermen must pay independently.

(3) Fishing equipment and ship assistance. This assistance is specifically aimed at small and traditional fishermen. With this subsidy, it is expected to reduce the operational costs of fishermen to catch fish. However, the assistance provided is more instantaneous so that it cannot direct fishermen to live independently to achieve welfare. This assistance cannot last in the long term because of limited government funding.

Thus, regulations on the empowerment of fishermen in Indonesia are regulated in the Law on the Protection and Empowerment of Fishermen, Fish Cultivators, and Salt Farmers which have been realized in government programs in the form of coastal economic empowerment programs (PEMP), fishermen insurance premium subsidy programs in the first year, and help of fishing gear / boat for small and traditional fishermen. For the regulation of the Marine Law, the Fisheries Law and the Management of Coastal and Small Islands Regulations concerning marine management so that they can be used effectively and efficiently and provide opportunities for small and traditional fishermen to also be able to utilize sea products optimally so that they are no less competitive with big fishermen.

\section{2) Legal Politic of Fishermen Empowerment in} Indonesia

Legal politics briefly means legal policy. Own policy in the Indonesian Dictionary (KBBI) means a series of concepts and principles that become the outline and basis in the implementation of work, leadership, and way of acting. [11] In other words, political politics is a series of concepts and principles that form the outline and basis of plans in the implementation of a work, leadership, and way of acting in the legal field.

Padmo Wahjono in Imam Syaukani and A. Ahsin Thohari, gave an understanding of legal politics as "the basic policy that determines the direction, form and content of the law to be formed". [12] This definition is still so simple and then supplemented again, that the legal politics is the state's policy regarding what is used as a criterion to punish something. The policy can be related to "the formation of law, the application of law and law enforcement". [13] Legal politics here is defined as public policy or policy which is focused on the context of fishermen empowerment in Indonesia that have been formed and implemented.

The fishermen existence needs special attention because there are still many fishermen whose lives are far from prosperous. As mandated by the Preamble of the 1945 Constitution of the Republic of Indonesia (1945 Republic of Indonesia) and the explanation of the Law on the Protection and Empowerment of Fishermen, Fish Cultivators, and Salt Farmers which imposes responsibilities to the state to be able to realize the goals of the country that is to protect all Indonesians and the whole of Indonesia's blood, promote public welfare, educate the nation's life, and realize social 
justice for all Indonesian people in accordance with the mandate of the Pancasila and the 1945 Constitution of the Republic of Indonesia. One of the basic philosophies of nation building is to realize social justice for all people Indonesia. Therefore, every Indonesian citizen has the right and obligation in accordance with his ability to participate in business development to improve welfare, especially in the field of fisheries as an effort to improve the welfare of fishermen whose business is related to fishing.

When viewed from the current regulations, these regulations refer to 3 (three) aspects of the development of the marine sector, namely economic, ecological and social aspects. Many economic aspects are regulated in the Law on the Protection and Empowerment of Fishermen, Fish Cultivators, and Salt Farmers wherein the Law regulates the institutional harmony of fishermen which is expected to increase to become fishing cooperative, providing fishermen insurance and premium subsidies in the first year, as well as providing assistance for small and traditional fishermen.

Marine ecological aspects have been regulated by the Law on Management of Coastal Areas and Small Islands and their amendments governing restrictions on the use of coastal areas by any party who wishes to utilize the coastal area so that the ecosystem is maintained and sustainable.

The social aspects of marine affairs are related to the handling of fishermen conflicts due to territorial boundaries and means of business of fishermen caused by the economic disparity between fishermen. This happens because of increasingly fierce competition with the nature of the fish resources use in the sea which are still "common property" and tend to have no restrictions on capture (open access), as well as the implementation of the era of regional autonomy that is misinterpreted. [14] This was overcome by the existence of regulations on Maritime Law and Fisheries Law whose substance regulates IUU (Illegal, Unreported, and Unregulated) and law enforcement.

Based on the Law on the Protection and Empowerment of Fishermen, Fish Cultivators, and Salt Farmers, it can be seen that the strategies for empowering fishermen are as follows:

(1) Development of access to capital

(2) Development of technology and scale of fisheries business

(3) Development of marketing access

(4) Institutional strengthening of fishermen and coastal communities

(5) Community-based fisheries resource management

(6) Development of facilities and infrastructure to support fishing businesses.

The fishermen empowerment strategy is form of legal politics of fishermen empowerment in Indonesia in the future where the direction will make it easier for fishermen regarding access to capital and access to marketing as well as providing assistance for technological development and institutional strengthening of fishermen. In addition, the government will also build facilities and infrastructure to support fisheries business activities as a stimulus to develop fisheries businesses.
Thus, the legal politic of fishermen empowerment in Indonesia is regulated in the Law on the Protection and Empowerment of Fishermen, Fish Cultivators, and Salt Farmers as a form of economic sector development. While the political law of other marine sector development includes development in ecological and social aspects. Ecological aspects are regulated through the Management of Coastal Areas and Small Islands and their amendments governing restrictions on the use of coastal areas. The social aspects of marine related to the handling of fishermen conflicts due to territorial boundaries and means of business of fishermen which are caused by economic gaps between fishermen are overcome by the existence of regulations on the Maritime Law and Fisheries Law whose substance regulates about IUU (Illegal, Unreported, and Unregulated) and law enforcement.

\section{CONCLUSION}

The conclusion is that regulations regarding maritime affairs in Indonesia consist of 4 (four) laws which each has the respective scope, namely fishermen empowerment, marine ecological protection, and resolution of fishermen's social problems due to fishermen gaps. The Law on the Protection and Empowerment of Fishermen, Fish Cultivators, and Salt Farmers has provided an overview about the political direction of the fishermen empowerment in Indonesia which includes facilities for fishermen regarding access to capital and access to marketing as well as assistance for technological development and institutional strengthening for fishermen. Beside that the construction of facilities and infrastructure to support fisheries business activities as stimulus to develop fisheries businesses.

\section{ACKNOWLEDGMENT}

This article is part of publication for research findings on model of fishermen poverty alleviation in the area of fishermen through institutional strengthening of fishermen association. Therefore, we thank the Institute of Research and Community Services at the Trunojoyo University of Madura for funding research on model of poverty management for marine fishermen through institutional strengthening of fishermen association in 2020.

\section{REFERENCES}

[1] Quoted from https://tirto.id/pemerintah-targetkan-indonesia-miliki-1juta-nelayan-berdaulat-dlwg accessed on 12 June 2020

[2] https://www.bps.go.id/pressrelease/2018/07/16/1483/persentasependuduk-miskin-maret-2018-turun-menjadi-9-82-persen.html accessed on 1 April 2019.

[3] Rokhmin quoted from https://republika.co.id/berita/ekonomi/korporasi/18/11/15/pi7qdl383guru-besar-ipb-sampaikan-penyebab-nelayan-indonesia-miskin. accessed on 1 June 2020,

[4] Akhmad Solihin, The Economic Rights of Indonesian Traditional Fishermen in the Border Area, available at https://pustakahpi.kemlu.go.id/app/Volume\%203,\%20SeptemberDesember\%202011 9 17.PDF, accessed on 27 March 2019.

[5] Jamaluddin Hos and Muhammad Arsyad, Poverty Factors of Fishermen Families in Tanjung Tiram Village, North Moramo District, South Konawe District, Journal of Sociology of Thought and Research; Volume 1, No. 1, April 2014, p. 57.

[6] B. M. and R. S. S, "Spiritual Capital and Social Welfare in Indonesia," Proc. Int. Conf. Democr. Account. Gov. (ICODAG 2017), 
https//www.atlantis-press.com/proceedings/icodag-17/25886184., 2017.

[7] Aprilina Pawestri, Lucky Dafira Nugroho, and Helmy Boemiya, "The Fulfillment of The Fishermen's Right to Achieve Welfare as a Part of State Responsibilities", Proc. 2nd. Int. Conf on Social Science (ICSS 2019), Advances in Social Science, Education and Humanities Research, volume 363, p. 1152, https://www.atlantispress.com/proceedings/icss-19/125927048

[8] Ibid.

[9] General Explanation of the Fisheries Law.

[10] Quoted from https://www.kompasiana.com/rajabaliakbar/5694b3ad81afbd6207b03 fce/strategy-empowerment-reserve-poor- accessed on 3 June 2020.

[11] Followed by KBBI Online which can be accessed at the link https://kbbi.web.id/bijak.

[12] Imam Syaukani and A. Ahsin Thohari, Fundamentals of Political Law, Raja Grafindo Persada, Jakarta, 2004, p. 22.

[13] Ibid.

[14] Directorate of Marine and Fisheries, Ministry of PPN / BAPPENAS RI, Study of Sustainable Fisheries Management Strategies, 20164, p. 5-20. 